AperTO - Archivio Istituzionale Open Access dell'Università di Torino

\title{
Geografiscal federalism
}

\section{This is a pre print version of the following article:}

Original Citation:

\section{Availability:}

This version is available http://hdl.handle.net/2318/1508352

since 2016-07-11T12:41:11Z

Publisher:

EDWARD ELGAR PUBLISHING

Published version:

DOI: $10.4337 / 9780857932297$

Terms of use:

Open Access

Anyone can freely access the full text of works made available as "Open Access". Works made available under a Creative Commons license can be used according to the terms and conditions of said license. Use of all other works requires consent of the right holder (author or publisher) if not exempted from copyright protection by the applicable law. 




This is an author version of the contribution published in:

Questa è la versione dell'autore dell'opera pubblicata in:

HANDBOOK OF MULTILEVEL FINANCE

E. Ahmad, G. Brosio (Eds.)

Edward Elgar, Cheltenham, UK, 2015

pp. $107-123$

The definitive version is available at:

La versione definitiva è disponibile alla URL:

www.elgaronline.com 


\title{
Geografiscal federalism
}

\author{
Federico Revelli \\ ${\text { (University of Torino })^{1}}^{1}$
}

\begin{abstract}
Spatial econometrics methods have been extensively applied to the analysis of decentralized fiscal policy-making in the past two decades, with most research focussing on the investigation of spatial patterns arising from various forms of competition among local authorities. This chapter first reviews the several contributions in the spatial analysis of local government data that have appeared since the publication of the first edition of the Handbook of Fiscal Federalism (2006) - over seventy fresh empirical works - with the aim of evaluating the advancements that have been made since then in the knowledge and understanding of interjurisdictional competition phenomena. The second part of the chapter discusses the impact on the empirical analysis of intergovernmental fiscal interaction of a number of recent econometric developments concerning the specification, estimation and interpretation of spatial models, and concludes with some remarks on the foreseeable developments in geografiscal federalism research.
\end{abstract}

\section{Introduction}

In the past two decades, public economists have increasingly employed spatial econometrics techniques to investigate the phenomenon of horizontal and vertical competition among governments in multitiered public sector structures. The use of geographical concepts and methods in empirical work on

${ }^{1}$ Department of Economics, Campus Luigi Einaudi, Lungo Dora Siena 100A, 10153 Torino (Italy). Tel: 
fiscal federalism - geografiscal federalism - is justified by the idea that space is an important aspect of multi-tiered fiscal arrangements, as witnessed by the plethora of theoretical work based on the two most prominent spatial concepts in public economics - Oates' decentralization theorem and the Tiebout sorting mechanism - as well as by the common finding that decentralized fiscal policies tend to exhibit positive spatial autocorrelation.

As discussed in Revelli (2006), the mainstream view among applied public economists through the 1990s and the early 2000s was that spatial econometrics provided powerful tools to identify substantive strategic interaction among decentralized decision-makers, and promised to be able to discriminate economically relevant processes of competition (substantive interaction) from the physiological correlation in local government budgetary data that is mechanically driven by purely geographical factors that have no behavioral significance (omitted variables in the empirical model). In addition, applied public economists have for over a decade set themselves the ambitious task of identifying the root cause of interaction, i.e., determining what kind of economic process is at work when local policies exhibit spatial autocorrelation: tax competition, yardstick competition, or benefit spillovers from decentralized provision of public services.

In order to discriminate between true interaction arising from intergovernmental competition and nonbehavioral correlation due to omitted variables, and to identify the politico-economic process generating such interaction, applied public economists have conventionally gathered rich datasets on decentralized governments' policies and characteristics, and borrowed the standard spatial econometrics toolbox to specify and estimate models of decentralized fiscal policy-making.

The typical empirical framework consists of three fundamental components, to which spatial considerations are added in a more or less ad hoc fashion:

a) a policy variable of interest, say a vector of tax rates, expenditure levels or efficiency scores (denoted by $\pi_{i t}$ from now on), that is observed in a cross-section $(i=1, \ldots, N)$ - more frequently in a repeated cross-section $(t=1, \ldots, T)$ - of local governments; b) a sensible, stylized, reduced-form economic model suggesting a vector of strictly exogenous variables $\mathbf{x}_{i t}$ that can be thought to directly affect $\pi_{i t}$ in a non-spatial framework, with the residual component of the policy variable $\varepsilon_{i t}$ being orthogonal to $\mathbf{x}_{i t}, E\left(\varepsilon_{i t} \mid \mathbf{x}_{i 1}, \mathbf{x}_{i 2}, \ldots, \mathbf{x}_{i T}\right)=0$ :

$$
\pi_{i t}=\mathbf{x}_{i t}^{\prime} \beta+\varepsilon_{i t}
$$

+390116704920; e-mail: federico.revelli@unito.it. 
c) a set of additional exogenous variables $\mathbf{Z}$ that allow the researcher to model the linkages between pairs of jurisdictions $\mathrm{i}$ and $\mathbf{j}$. The $\mathbf{Z}$ variables are typically related to the location of jurisdictions in space, such as spatial coordinates, and transformed into a spatial weights matrix that is conventionally termed W.

The first step of the empirical approach consists in the estimation by standard linear methods of equation (1) and application of a number of well established tests on its residuals in order to ascertain whether a spatial approach is indeed required. What form the spatial process should be given, though, is the most challenging question that applied spatial econometricians need to answer (Pinkse and Slade, 2010). In general, the problem consists in learning about the nature of a spatial function $s$ such that:

$$
s(\mathbf{D})=s(\boldsymbol{\pi} \mathbf{X} \mathbf{Z})=\mathbf{u}
$$

Where $\mathbf{D}$ is the $\left(N T \times\left[k_{1}+k_{2}+1\right]\right)$ matrix containing the data, with (location, time) observations being stacked by year, $\pi$ is the $(N T \times 1)$ vector of policy variables, $\mathbf{X}$ is the $\left(N T \times k_{1}\right)$ matrix of exogenous variables, $\mathbf{Z}$ is the $\left(N T \times k_{2}\right)$ matrix of locational attributes, and $\mathbf{u}$ is an $(N T \times 1)$ vector of independently and identically distributed errors.

Clearly, the NT-dimensional function s can be estimated only by imposing a number of restrictions. The most common sets of restrictions imposed on (2) lead to fully parametric specifications that are highly parsimonious in that they typically model the entire spatial dependence structure by means of a single unknown parameter. ${ }^{2}$ This leads to the two prominent spatial specifications that have been widely employed by applied public economists, that is a first order spatial autoregressive model (SAR(1)) - also known as the spatial lag model - reported in equation (3) below, or a first order spatial autoregressive error process - or spatial error model - reported in (4):

$$
\begin{gathered}
\left(\mathbf{I}_{N T}-\rho \mathbf{W}\right) \boldsymbol{\pi}-\mathbf{X} \boldsymbol{\beta}=\mathbf{u} \\
\left(\mathbf{I}_{N T}-\lambda \mathbf{W}\right)(\boldsymbol{\pi}-\mathbf{X} \boldsymbol{\beta})=\mathbf{u}
\end{gathered}
$$

where: $\rho$ and $\lambda$ are scalar coefficients capturing the nature of the respective spatial structure, with $0<\rho<1$ and $0<\lambda<1, \mathbf{W}=\left[I_{T} \otimes W_{N}\right]$ is a block-diagonal, row-standardized matrix of nonstochastic weights built on localities' spatial attributes $\mathrm{Z}, \mathbf{I}_{N T}$ and $I_{T}$ index the identity matrices of sizes

\footnotetext{
${ }^{2}$ McMillen (2010) advocates the use of nonparametric techniques.
} 
NT and T respectively, and $W_{N}=\left\{w_{i j}\right\}, i, j=1, \ldots, N$. According to the conventional and widely employed binary contiguity criterion and upon row-normalization, the link between localities $\mathrm{i}$ and $\mathrm{j}$ $\left(w_{i j}\right)$ equals $\frac{1}{n_{i}}$ if jurisdiction $\mathrm{j}$ is adjacent (say, shares a common border) to jurisdiction $\mathrm{i}, 0$ otherwise, with $n_{i}$ being the number of units being adjacent to (sharing borders with) unit $\mathrm{i}$. The empirical models (2) and (3) can be estimated by a variety of methods relying either on the maximum likelihood principle if one is willing to make distributional assumptions on $\mathbf{u}$, or on moment conditions arising from the hypothesis of strict exogeneity of $\mathbf{X}$ and its spatial transformations $\mathbf{W X}, \mathbf{W}^{2} \mathbf{X}, \ldots{ }^{3}$

Most of the literature presented in section 2 below follows variants of the above described modelling and estimation approach. As such, it constitutes a sort of first generation empirical fiscal competition literature. The second generation is just at its beginning, and is introduced and discussed in section $\mathbf{3}$ of the chapter: it tackles directly a number of issues that emerge when trying to identify the spatial function $s$, with the main objective of obtaining empirical evidence that can be attributed a causal interpretation. Some remarks on the foreseeable developments in geografiscal federalism research are contained in the concluding section 4.

\section{Literature review 2005-}

\subsection{Tax competition}

The earliest empirical works on intergovernmental competition were for the most part motivated by the objective of quantifying the externalities and spillovers from decentralized expenditures on public services on neighboring governments. ${ }^{4}$ However, also due to the increasing degree of devolution of taxing power to local governments, the literature that followed during the late 1990s and early 2000s decisively turned its attention to various forms of tax competition, where the key objects of interest were local tax rates and their spatial patterns. Most of the empirical research that appeared in the most recent years has indeed continued in that direction by further investigating the determination process of

\footnotetext{
${ }^{3}$ Bayesian approaches to spatial model testing and estimation are discussed at length in Le Sage and Pace (2009).

${ }^{4}$ Those early contributions are discussed in Revelli (2006).
} 
local tax rates in a spatial framework, and trying to discriminate between information-based yardstick competition and mobility-based Tiebout processes.

While a variety of institutional set-ups and country data have been scrutinized, most works have relied on a common empirical approach based on applications of the spatial lag dependence model (spatial lag) on cross-sectional or panel data from European countries and US states. Amongst them, Allers and Elhorst (2005) use Dutch municipalities' panel data to test for yardstick competition, and find evidence of tax mimicking in unanticipated tax rate differentials using a two-regime spatial model based on political strength of local governments. Edmark and Agren (2008) rely on Swedish municipalities' panel data and aim at distinguishing between the two processes - yardstick versus tax competition - by using a reform of the central government grant system. Since the grant reform changed the criteria of tax base equalization of the Swedish municipalities, the idea is that any change in the degree of spatial interaction after the grant reform can be viewed as indirect evidence of altered incentives to tax competition for mobile bases. They then test two empirical implications descending from yardstick competition, namely that yardstick-type interaction should be expected to be stronger during election years and when the political majority is weak. Brülhart and Parchet (2010) investigate the reasons for the disappearance of inheritance taxes in Switzerland, and conclude that tax competition is unlikely to be responsible for it. Feld and Reulier (2009) use panel data to test for tax competition in Switzerland. They find significant positive spatial autocorrelation in cantons' income tax rates, with the correlation being particularly strong for the most mobile middle-income taxpayers. Delgado and Mayor (2010) and Delgado et al. (2011) test the tax competition hypothesis in Spain. Gerard et al. (2010) use a long panel dataset on Belgian municipalities and find evidence of interaction among close neighbors in the setting of the local surcharge on income tax, but not of the local surcharge on property tax. Moreover, they allow for interregional differences in spatial patterns using the fact that Belgian regions (Wallonia, Flanders and Brussels) differ on political, economic, linguistic and cultural dimensions, and find that the intensity of spatial interaction processes is higher within than between regions. Santolini (2008, 2009) sets up a theoretical model where politicians mimic the fiscal policies of their peers (politicians from the same party) in order to advance platforms that are aligned with the party's ideology, and tests the mimicking hypothesis on cross-sectional data from the Italian region of Marche. The empirical evidence indeed suggests that municipalities controlled by ideologically similar governments tend to implement similar tax policies. Cassette et al. (2012) use a panel data set of municipalities in France and Germany along the Rhine Valley, thus exploiting the fact that local governments in the two countries can influence the overall tax burden of firms via different tax instruments. Finally, based on 
US state panel data for almost thirty years, Deskins and Hill (2010) document that the intensity of interstate fiscal interaction diminished over time.

A number of works test simultaneously for horizontal and vertical fiscal externalities. Leprince at al. (2007) study business tax interactions in France and allow both for vertical (department-region) and horizontal (cross-departments) externalities. Using cross sectional data from 1995, they find that business tax competition among departments is a significant feature of the French multi-tiered business tax (taxe professionelle) system, whether or not vertical interactions are allowed for. Devereux et al. (2007) use US state panel data to test for competition in excise tax setting, and find evidence of horizontal competition for cigarette taxes, and vertical competition for gasoline taxes. Hoffer (2011) obtains similar results: he tests for vertical (state-federal) and horizontal (inter-state) competition in cigarette excise taxes using US state-level data 2000-2007, and finds that high incentives for interstate arbitrage (cross-border shopping) make states highly competitive and responsive horizontally, but not vertically. Lovenheim (2008) uses micro-data on cigarette consumption combined with geographic information on the location of consumers with respect to lower-price jurisdictions to estimate cigarette demand models that incorporate the decision of whether to smuggle cigarettes across states. Burge and Rogers (2011) investigate vertical and horizontal fiscal spillovers in local option sales taxes (LOST) i.e., general retail sales taxes imposed in over 30 US states at the municipal or county level, where the proceeds are returned to the local jurisdiction of the purchase location. In particular, they use panel data for municipalities and counties in the US state of Oklahoma to show that the ability of municipal governments to control LOST revenues by varying their own tax rate is affected by both vertical and horizontal fiscal externalities. Similar results emerge in Wu and Hendrick (2009) based on Florida local governments' property tax data.

Finally, other aspects of decentralized revenue raising efforts have been recently analyzed to uncover spatial patterns of competition. Allers and Hoeben (2010) and Rork (2009) test for competition in the setting of unit-based garbage pricing and toll revenues respectively. Brown and Rork (2005) and Knight and Schiff (2010) investigate the spatial patterns created by US state lotteries. The former test whether the implicit tax (the amount of sales collected but not redistributed as prizes) is correlated across states, and find that if neighboring states lower their lottery tax, the home state responds by lowering it too. The latter find significant evidence of cross-border lottery shopping leading to competitive pressure from neighboring states. 


\subsection{Laboratory federalism: discrete adoption choices in space}

Spry (2005), Ashworth et al. (2006), Rincke (2006a, 2006b, 2007, 2009), Fiva and Rattso (2007), Hall and Ross (2010), Sjoquist et al. (2007) and Burge and Piper (2012) turn their attention to local governments' discrete, binary choices about the introduction of novel forms of taxation or public service organization, and investigate whether those choices are affected by neighboring authorities' behavior.

In particular, Spry (2005) addresses the questions of what determines whether a local government adopts an income tax and the percentage of the local revenue that is raised from the income tax. He uses data on the Ohio school district income tax (SDIT) - a local income tax that school districts can levy on the Ohio adjusted gross income of residents - and estimates a probit model and a Tobit model to answer those questions, finding evidence that fiscal competition for mobile consumers (proxied by the number of nearby school districts within a given distance) limits the ability of local governments to use a local income tax. In a related paper, Hall and Ross (2010) use a spatial autoregressive probit model to test on over 600 Ohio school districts if the likelihood of a school district adopting the income tax is a function of whether a district's neighbors have adopted the tax. In order to control for the potential bias due to spatially dependent omitted variables in a cross-section, they implement a spatial Durbin probit by Bayesian methods, that is a model where the propensity of a school district to adopt the income tax is a function of neighboring districts' propensities to adopt it as well as those districts' characteristics. They find evidence of significant spillovers, in the sense that the probability of passing an income tax is higher in school districts whose neighbors already use the income tax.

Policy diffusion, incentives to emulate and yardstick competition between school districts in the US are deeply scrutinized by Rincke (2006a, 2006b, 2007, 2009), who consistently shows that policy innovation in school districts (inter-district choice programs, open enrollment schemes, charter schools) exhibits a spatial pattern that is best analyzed by means of spatial limited (discrete) dependent variable models. On the other hand, Sjoquist et al. (2007) and Burge and Piper (2012) investigate the determinants of local option sales taxes adoption in Georgia and in Oklahoma respectively. They model option sales tax adoption with a duration approach, where the time to adoption is allowed to be influenced by neighboring counties' adoptions. Estimation of discrete time hazard models reveals that in both states local governments are likely to adopt sales tax programs earlier if their neighbors have also done so.

As far as Europe is concerned, Fiva and Rattso (2007) consider the choice of whether having 
residential property taxation by local governments in Norway. They employ a Bayesian approach to tackle simultaneous spatial dependence in the binary decision variable, and implement it on a crosssection of Norwegian local government data, finding evidence of fiscal competition that, with limited mobility of the tax base and politically highly visible decisions, they interpret as compatible with yardstick competition. Ashworth et al. (2006) analyze the determinants of the diffusion process of the adoption of a green tax in Belgium: using panel data for the 308 Flemish municipalities for the period 1991-1999, they estimate a discrete hazard model where the probability of a municipality introducing a green tax is allowed to depend on the percentage of first-order as well as second-order neighboring municipalities that have already adopted the tax in the previous period, finding that both variables have a positive effect. Moreover, the decisions of ideological neighbors - i.e., authorities that are close in terms of political affiliation - are found to have a similar impact, irrespective of geographical proximity.

\subsection{Spatial interaction with tax limits}

Some recent research has investigated the consequences of tax and expenditure limitations (TELs) on the spatial pattern of local fiscal policies. Explicit incorporation of TELs in the specification and estimation of fiscal reaction functions is justified by the observation that local governments around the world are frequently subject to stringent regulations on their tax and spending decisions. This makes the ideal paradigm of unleashed intergovernmental competition sort of blurred in practice. In fact, local tax rate limitations are observed almost everywhere. In the US states, property tax limits date back as early as the 1930s, and became widespread after California's Proposition 13 in the late 1970s. In Europe, local tax limitations are in place in virtually all countries, most frequently including all main local sources of own revenue - property, business and consumption taxes. A frequently encountered case is a cap on a local tax policy, ideally calling for a corner solution model accounting for clustering at the limit. Overlooking the fact that a number of local authorities might be constrained is bound to lead to similar problems as the ones that are encountered in non-spatial econometric settings when the dependent variable is limited. In particular, estimates of the reaction function slope will tend to be biased. Intuitively, authorities hitting the limits give the false impression of deliberately setting their policies independently of their competitors (in either tax or yardstick competition frameworks), while being in reality constrained by fiscal limitations to do so. 
Luna et al. (2007) examine Tennessee counties' option sales taxes between 1975 and 1999, with county tax rates being legally constrained by a state cap of $2.25 \%$ in the $1975-1984$ window, and of $2.75 \%$ in the rest of the period. They show that county sales tax rates generally increased over time, with all 95 counties having positive tax rates and about half of them being capped at the maximum rate in 1984, and about $20 \%$ of them reaching the higher bound by 1999 . To examine the role of economic and political factors in the decision to raise sales tax rates and eventually end up against the tax limit, they use a duration model that uses as the key variable the spell of time spent below the tax cap. To allow for neighborhood influences on the probability that a county ends in the corner solution, they use two variables. The first is the average sales tax rate of contiguous counties weighted by population, based on the assumption that larger neighboring counties are more likely to have an impact on the county's tax rate. The second is a dummy variable that takes a value of one for a border county and a value of zero for an interior county, with the expectation that border counties will keep their local tax rates low to limit cross--border shopping arising from combined state and local sales tax differentials. While their survival analysis does not reveal any significant influence from neighboring counties, they acknowledge the complexity of a simultaneous spatial tax competition empirical model and call for further research in this area.

Wu and Merriman (2011) use the introduction of a simplified local telecommunications tax in Illinois in 2003 to examine municipalities' tax setting choices in the subsequent years. The new system allowed municipalities to choose a tax rate between 0 and 6 percent of the gross charge for telecommunications purchased at retail. Between 2003 and 2008, the number of municipalities that did not set the tax dropped slightly, while the number of municipalities that were capped at the top rate increased significantly. When analyzing the determinants of the evolution of those tax rates over time, they find evidence of inertia effects in the sense that municipalities that had a zero tax rate at the time of introduction of the tax tended not to set positive tax rates subsequently, and the municipalities that were capped at the maximum rate tended not to revert from there. They do find evidence of neighboring effects, though: once allowing for inertial behavior of corner solution authorities, high or increasing tax rates in adjacent municipalities are estimated to make own tax increases more likely.

Di Porto and Revelli (2013) explicitly model a spatial process in local tax policies in the presence of centrally imposed fiscal limitations. In order to investigate the effect of those limitations on the intensity of intergovernmental competition, they take the conventional empirical model of the fiscal reaction function - the spatial lag specification that does not account for corner solutions at the tax limits - as the benchmark, and implement three empirical approaches to the analysis of spatially 
dependent limited tax policies: 1) a Bayesian spatial approach for censored dependent variables; 2) a Tobit corner solution model augmented with a spatial lag; 3) a spatial discrete hazard model focusing on the corner solution outcomes. ${ }^{5}$ Based on an empirical application to provincial vehicle taxation in Italy, they find that explicitly allowing for corner solutions generated by tax limitations unveils a significantly stronger spatial dependence process than when employing conventional approaches. They also show that the performance and usefulness of those modelling approaches depend on their ability to capture the specific features of the institutional framework under consideration, the nature of the statelocal government structure and the binding intensity of the tax limitations in force.

\subsection{The other side of the budget: spatial interaction in public expenditures}

Along the continuing empirical work on tax competition, attention has recently turned back to the expenditure side of the budget and to the spatial analysis of various types and categories of local spending. Based on French municipalities' data, Foucault et al. (2008) find evidence of opportunistic strategic behavior in current and investment expenditure setting behavior, and Choumert and Cormier (2011) test for benefit spillovers among local authorities in the provision of urban parks and green spaces. Lundberg (2006), Werck et al. (2008) and Dalle Nogare and Galizzi (2011) explore spatial dependence in local spending on culture in different institutional settings. Rincke (2010) proposes a commuting-adjusted weighting scheme and shows the sensitivity of the results of estimation of a spatial lag model of local police spending in the US. Solé-Ollé (2006) models two distinct forms of spillovers: benefit spillovers from the provision of non-rival local public goods and crowding spillovers arising from the use of rival local facilities by non-residents. Based on cross-sectional data on over 2500 Spanish local governments, estimation of an expenditure reaction function reveals that both types of spillovers are relevant. Stastna (2009) finds evidence of expenditure mimicking among local authorities in the Czech Republic as far as spending on housing and culture is concerned, while negative spatial interdependence for expenditures on industry, infrastructure and environmental protection is taken as a symptom of benefit spillovers making neighbors' expenditures on those services substitutes for own spending. Agostini et al. (2010) use panel data on 86 rural Chinese administrative villages and find

${ }^{5}$ Flores-Lagunes and Schnier (2011) propose instead an estimator for a sample selection model with spatial error dependence; Klier and McMillen (2008) construct a linearized logit model for spatially dependent discrete choices. Those two approaches might turn out to be useful for discrete choice applications in empirical local public economics. 
evidence that per capita spending on public projects in neighboring villages significantly increases spending in the home village, and argue that transition to democracy stimulates those neighborhood effects. Ermini and Santolini (2010) investigate the spatial pattern of general and categorical public expenditures in a cross-section of Italian municipalities. Since they do not find any evidence of opportunistic or electoral motivation in spending determination, they attribute the observed spatial pattern to spillovers making municipal services complementary, and possibly to the presence of explicit forms of intermunicipal cooperation and partnership. However, in a subsequent analysis based on a panel dataset for roughly the same sample of municipalities, Bartolini and Santolini (2011) show that explicit consideration of a number of electoral and institutional constraints on mayors allows to identify different behavioral patterns that are consistent with the idea of strategic mimicking due to yardstick competition.

A strand of the literature focuses on decentralized welfare spending. Dahlberg and Edmark (2008) test the race to the bottom hypothesis on benefit levels in Sweden. Birkelof (2009, 2010) studies Swedish municipalities' expenditures on services directed to people with major and long-term functional disabilities, and finds that spatial dependence in spending per capita on those services decreases substantially after the introduction of an equalization grant mechanism that relies on standardized provision costs. Fiva and Rattso (2006) and Fiva (2009) provide evidence of strategic interaction among Norwegian municipalities in setting benefit levels. Moscone and Knapp (2005), Moscone et al. (2007), and Moscone (2011) find evidence of spatial dependence in mental health and learning disabilities by the English local authorities, while Costa-Font and Pons-Novell (2007) and Costa-Font and Moscone (2008) examine the spatial pattern of regional public health expenditure in Spain. Finally, recent studies go beyond the conventional single-equation approach and introduce spatial aspects in the overall fiscal policy-making process of local authorities. Hauptmeier et al. (2008) derive from a theoretical fiscal competition framework a two-equation empirical model composed of structural reaction functions for capital tax rate and a public input, and implement it on a panel dataset for municipalities in the German state of Baden-Wuerttemberg. The empirical analysis reveals a complex pattern of interactions across the two simultaneously set policy instruments, and suggests a rather flexible form of competition among local jurisdictions to attract mobile capital. Geys and Revelli (2011) study the tax mix determination process - that is, the simultaneous choice of the vector of local tax rates in the presence of multiple own sources of revenue - using Flemish municipalities' panel data, and test for spatial dependence in the residuals from estimation of a system of reduced-form tax revenue-share equations. They find that the observed spatial pattern in the local tax mix of Flemish 
authorities is driven almost entirely by the fact that contiguous municipalities have similar socioeconomic structures influencing their tax mix choices in similar directions. Allers and Elhorst (2011) use an extended version of the LES (linear expenditure system) with policy interaction effects to simultaneously estimate interactions in both taxation and (six) different spending categories among Dutch municipalities. They explicitly derive an extended version of the LES that accounts for spatial dependence and interjurisdictional differences in unit costs of public services from a formal social welfare maximization problem subject to the jurisdiction's budget constraint. Their estimates of the spatial interaction parameters tend to be higher than those obtained in conventional single equation models that introduce a spatial lag in an ad hoc fashion. Finally, Fletcher and Murray (2006) analyze the overall structure of US states' sales taxes - including tax base definition and needy consumers and business exemptions. The interstate tax base definition pattern that emerges is not a purely geographic one, but appears to be driven by states' economic and fiscal dimensions.

\subsection{Local government efficiency, popularity and the media}

Whether the revenue or the expenditure side of the budget is considered, though, yardstick competition remains among the most popular explanations of why decentralized governments interact with each other and tend to exhibit interdependent policy outcomes. In fact, empirical applications of political economy models are where the most innovative attempts have been made to unveil the network of dependence and to measure the performance of decentralized governments.

In a way, yardstick competition owes its popularity to the fact that Tiebout mobility seems patently unrealistic in a number of countries (particularly in Europe), while information spillovers across localities are easier to believe in, and are well documented. Moreover, an unpleasant aspect of the Tiebout model for empirical researchers employing spatial econometrics techniques is that household sorting into locations based on heterogeneous tastes for local public services is bound almost by definition to yield no clear empirical prediction in terms of spatial dependence of tax and public service bundles.

Recents tests of the yardstick competition hypothesis have proceeded along two parallel ways. On the one hand, researchers have employed increasingly sophisticated measures of local government performance and checked their degree of correlation along geographic as well as more imaginative dimensions, such as deeper investigations of the channels (the media) through which information spills 
over. Recent empirical applications to Belgium (Geys, 2006), England (Revelli, 2007), and Norway (Revelli and Tovmo, 2007; Bruns and Himmler, 2011) use various measures of efficiency in local provision of public services and point to the potentially important role played by information spillovers and local media networks in affecting the spatial pattern of local government performance. On

the other hand, Vermeir and Heyndels (2006), Bosch and Solé-Ollé (2007), Revelli (2008) and Dubois and Paty (2010) follow the yardstick voting approach, and estimate vote or re-election equations that allow for an effect from own as well as from neighboring authorities' tax and public service performance indicators on the popularity of incumbent governments. In some of those works, the neighborhood concept is enlarged to embrace the role of the media structure (Revelli, 2008) or of similarity in terms of demographic characteristics that transcend purely geographical patterns (Dubois and Paty, 2010).

\section{Recent developments}

While the above section shows how lively the empirical literature on fiscal interaction has been in the past few years, the turn of the decade has marked a change of pace in applied research. Such abrupt acceleration is characterized by a change of focus of empirical work as well as the adoption of novel spatial econometric techniques. I outline the most recent research in this area in the two following sections, dealing respectively with the call for more general spatial econometrics models than the traditional spatial error and spatial lag ones (the so-called spatial Durbin model), and the deep criticism of structural spatial econometrics approaches stemming from the experimental paradigm concept.

\subsection{Specification and interpretation issues}

As argued by Elhorst (2010a), spatial econometrics has gone through a phase of substantial renovation in recent years, particularly thanks to some notable methodological contributions. The two most important novel aspects for spatial econometric applications are the call for the adoption of general spatial models such as the spatial Durbin one in place of the conventional spatial error and spatial lag ones, and the urge to focus on the direct, indirect and total marginal effects of the exogenous variables in the model, where those effects are indeed a function of the estimated autoregressive coefficient, but 
vary depending on the location of the observations (LeSage and Pace, 2009). ${ }^{6}$

First, the spatial Durbin model allows both neighbors' key policy variables $(\mathbf{W} \pi)$ and their relevant determinants (WX) to be included in an unrestricted form in the model of the determination of own policies:

$$
\pi=\phi \mathbf{W} \pi+\mathbf{X} \beta+\mathbf{W X} \boldsymbol{\theta}+\mathbf{u}
$$

According to Elhorst (2010a; 2010b), the main advantage of the spatial Durbin model relative to more restrictive specifications is that it produces unbiased coefficient estimates also if the true datagenerating process is a spatial lag or spatial error model. Recent empirical applications to local public finance contexts based on the spatial Durbin model are Elhorst and Freret (2009) and Beer and Riedl (2011).

Second, the recent spatial econometrics literature puts forward a slightly different interpretation of the key coefficients in spatial dependence models than it has been usually done in applied empirical work. It is stressed that the most important information that can be drawn from the estimation of spatial models is contained in the direct, indirect and total marginal effects of the exogenous variables in the model. In fact, those effects are a function of the estimated autoregressive coefficient - $\rho$ in equation (3), or $\phi$ in equation (5) - and depend on the location of the observations (LeSage and Pace, 2009). In particular, the direct and indirect marginal effects from a spatial lag and a spatial Durbin specification are based on:

$$
\begin{aligned}
& E(\pi)=M_{\rho} \mathbf{X} \beta=\left(I_{N T}-\rho \mathbf{W}\right)^{-1} \mathbf{X} \beta \\
& E(\boldsymbol{\pi})=M_{\phi}(\mathbf{X} \beta+\mathbf{W X} \boldsymbol{\theta})=\left(I_{N T}-\phi \mathbf{W}\right)^{-1}(\mathbf{X} \beta+\mathbf{W X} \boldsymbol{\theta})
\end{aligned}
$$

In the spatial lag model, the direct effects of the $\mathbf{x}_{i t}$ vector variables $\left(x_{i r t}, r=1, \ldots, R\right)$ on $\pi_{i t}$ $\left(\partial \pi_{i t} / \partial x_{i r t}=M_{\rho}(i, i) \beta_{r}\right)$ depend on the diagonal elements of the $M_{\rho}$ matrix, and capture the feedback loops from a change in $x_{i r t}$ on $\pi_{j t}(j \neq i)$ and back on $\pi_{i t}$, with $M_{\rho}(i, i) \geq 1$. In practice, the magnitude of the direct effects depends on the position of units in space and on their degree of

${ }^{6}$ LeSage and Domiguez (2011) stress the usefulness of spatial models - and of the spatial Durbin model 
connectivity with other units as determined by $\mathbf{W}$, and differs across units. Typically, average direct effects are based on the mean of the trace of matrix $M_{\rho}$, or they are computed for selected, relevant observations.

Conversely, the indirect effects $\partial \pi_{i t} / \partial x_{j r t}=M_{\rho}(i, j) \beta_{r}(j \neq i)$ rely on the off-diagonal elements of matrix $M_{\rho}$ and arise from the fact that a change in variable $r$ in a single unit can potentially affect all other units. Average indirect effects are based on the mean of the row (or column) sums of matrix $M_{\rho}$, and quantify the impact of a change in $x_{j r t}$ in all other units on $\pi_{i t}$ (or of a change in $x_{i r t}$ at a particular location on all other $\pi_{j t}$ ) via parameter $\rho$. Since the average row sum (total impact to an observation) and the average column sum (total impact from an observation) are equal, there is no practical difference in following either of the two approaches, though they have a different interpretation (LeSage and Pace, 2009, p. 37). A similar approach for computing direct and indirect marginal effects is followed in the spatial Durbin model, with the difference that a change in $x_{j r t}(j \neq i)$ affects $\pi_{i t}$ via the two parameters $\phi$ and $\theta_{r}$ (Elhorst, 2010).

\subsection{Discontinuities at borders}

However, a somewhat deeper criticism to conventional spatial econometrics approaches has been raised in a number of recent papers (Pinkse and Slade, 2010; McMillen, 2010; Gibbons and Overman, 2012) and concerns the weakness of conventional spatial econometric methods in terms of identification and causality. The criticism is based on the so-called experimental paradigm and stems from the need to identify causal effects in spatial models in roughly the same way as this is done in the other fields of applied economic research. In particular, it is argued that the standard spatial econometric models - including the spatial Durbin one - would be extremely difficult to distinguish from one another empirically, given that they all have virtually the same reduced form, where the variable of interest is a function of various spatial lags of the exogenous variables. As a result, the best one could obtain from those parametric specifications that model the entire spatial dependence structure up to single multiplicative coefficients would be some rough idea of the sign and strength of the spatial dependence in a variable of interest, something that would not represent an overwhelming gain relative to the insight provided by plain tests of spatial autocorrelation. This discouraging view is

in particular - in empirical public choice analyses. 
further worsened if one considers that consistent estimation of the $\beta$ parameter vector relies on the empirical model being correctly specified and the variables in $\mathrm{X}$ being strictly exogenous, and that, in the absence of compelling theoretical reasons, the spatial weights matrix $\mathrm{X}$ is usually chosen in an arbitrary way (Gibbons and Overman, 2012).

While various directions for future research in spatial econometrics have been recently proposed to overcome the above weaknesses, the one that is most relevant for local public finance applications is the need to look for exogenous variations in spatially coded variables. Exogenous variation in spatially linked locations should be able to overcome the physiological lack of valid spatial instruments when the matrix W is (arguably in most applications) incorrectly specified, and allow identification of the causal impact of policy changes in one jurisdiction on other jurisdictions. The search for an exogenous variation in space seems a reasonable empirical approach both when the researcher is interested in explicitly (and ambitiously, in the light of the above criticism) recovering the actual degree of policy interaction - i.e., estimating a fiscal reaction function with a spatial lag or spatial Durbin specification and when, in a more realistic and perhaps illuminating way, the fundamental research design consists in estimating the sensitivity of economic and political conditions in a jurisdiction to the fiscal policies set in the wider neighborhood within which jurisdictions are plausibly spatially linked. This means, for instance, testing whether business location, employment or election results in a locality are affected by tax and expenditure policies in nearby localities, where identification of the effects of the latter is bound to require some exogenous spatial variation that most likely arises from institutional aspects and reforms.

Recent public finance approaches that deal more or less explicitly with those criticisms and tackle the fiscal competition issue with identification and causality set at centre stage are Lyytikainen (2012), Reback (2011), Agrawal (2011), and Eugster and Parchet (2011). In various ways, these papers exploit exogenous spatial variations or discontinuities in order to identify fiscal competition phenomena. Lyytikainen (2012) tests for property tax competition among local governments in Finalnd by estimating a fiscal reaction function with an IV approach . The interesting innovation in that paper is the use of a property tax reform occurred in the year 2000 that increased the statutory lower limits to the property tax rates. For authorities that were setting in 1999 a lower tax rate than the new limit, the reform generates exogenous tax rate changes (forced increases) that can be used as instruments for changes in neighbors' tax rates in a spatial lag specification. In particular, since Lyytikainen (2012) realizes that corner solutions arise when authorities are against the new lower limit in the year 2000, he chooses to restrict his attention to municipalities for which the new lower limit is not binding (i.e., 
dropping the corner solution observations), and to estimate the response of the authorities in that smaller sub-sample to the tax rate changes in all neighboring authorities, whether or not they are constrained by the new limit, using as instruments the predicted imposed tax rate increases for corner solution observations. The empirical analysis conducted on the differenced cross-section 1999-2000 reveals virtually no response of unconstrained authorities - i.e., authorities setting rates well above the limit - to tax rate changes in the neighborhood. In general, the idea of exploiting the centralized tightening of the lower tax limits is novel and interesting. However, simply dropping the corner solution observations - i.e., the low tax authorities - is not without consequences, especially if those low tax authorities are the most sensitive to tax competition pressures, and high tax authorities that the analysis focusses on are the least, due, say, to agglomeration forces.

Reback (2011) uses a cross-state-border instrumental variable strategy in order to overcome the difficulties that arise when searching for valid instruments for neighboring authorities' policies in a spatial lag specification. In a two-tiered - state and local - system as the US, the idea is to look at the response of the policy of a local authority located, say, in state A, to the policies of neighboring authorities located along the border in state B, using districts located in state B at a long enough distance from the cross-state border as instruments. Since similar districts in the same state tend to be similarly affected by state policies, and state policies show a large variance across states, inner locality's fiscal policies are likely to be highly correlated with close to the border localities and therefore constitute relevant instruments. While the idea is interesting, the model still seems to suffer from an arbitrary definition of neighborhood and to a somewhat ad hoc specification imposing exclusion restrictions - own and out-of-state inner localities' policies - in the fiscal reaction function. Still, exploiting the patterns produced by multi-tiered government structures is definitely a promising field for further research.

Agrawal (2011) is an interesting attempt at estimating the local tax gradient, that is the effect of distance of a locality from a state border on the local sales tax rate in the presence of discontinuities at borders due to state sales tax rate differences. In particular, Agrawal follows a sort of regression discontinuity design. The treatment variable is not just the dichotomous state border discontinuity, but the actual size of the notch, that is the difference in sales tax rates among contiguous states. In practice, he models a flexible, non-linear relationship between the combined district-county sales tax rate in a locality and the distance from the nearest state border, and interacts the composite distance terms with the positive (own state setting a higher tax than the neighboring state) or negative (own state setting a lower tax than the neighboring state) notch size. While not directly estimating a tax reaction function, 
he finds indirect evidence of tax competition: distance to the border is a significant determinant of local option sales taxes, and local tax rates close to the border tend to partially offset interstate tax differences.

Finally, Eugster and Parchet (2011) aim at identifying tax competition among localities in Switzerland by exploiting discontinuities in voter preferences at language borders. Based on local outcomes of federal referenda on fiscal issues, they first show large differences in preferences and even discrete jumps in voting at language borders. They next show that localities that are far from the language border exhibit great differences too in local income tax rates (multipliers), with French-speaking localities setting significantly higher taxes on income than German-speaking ones. However, localities that are close to the border set similar fiscal policies irrespective of the language side of the border they find themselves. The authors interpret the smoothing of tax policies close to the border (a tax gradient) as driven by the mobility of taxpayers and their threat to relocate, with the tax differential approaching zero in spite of the difference in culture. While the authors exclude a yardstick competition force driving such convergence at the border, it remains unexplained how cross-border mobility can be so high in the presence of such large cultural differences.

\section{Concluding remarks}

Spatial econometrics methods have been extensively applied to the analysis of decentralized fiscal policy-making in the past two decades, with most research focussing on the investigation of spatial patterns arising from various forms of competition among local authorities. This chapter has reviewed the several contributions in the spatial analysis of local government data that have appeared since the publication of the first edition of the Handbook of Fiscal Federalism (2006) - over seventy fresh empirical works - with the aim of evaluating the advancements that have been made since then in the knowledge and understanding of interjurisdictional competition phenomena. The impressive number and diversity of empirical works that have investigated intergovernmental fiscal competition phenomena in the most recent years suggests that spatial fiscal interaction remains a core topic of applied research in fiscal federalism research. Scholars in this field have tackled a number of important issues, including conventional tax competition for mobile resources, spillovers from expenditures on local public services, and interdependence arising from imitation, policy diffusion and yardstick competition. Particularly interesting are the recent attempts to pursue new and more convincing 
empirical approaches that are able to deliver a causal interpretation of the estimated effects, based on careful recognition of institutional aspects (tax and expenditure limitations, exogenous policy changes at administrative borders) playing a crucial role in local government policy-making. This line of research seems the best suited to respond to the mounting dissatisfaction with mechanical applications of spatial econometric methods to the analysis of local government data, and the most promising in terms of potential for identification and proper interpretation of the undeniable role of space in the determination of decentralized fiscal policies.

\section{References}

Agostini C, Brown P, Zhang X. 2010. Neighbor effects in the provision of public goods in a young democracy: Evidence from China. International Food Policy Research Institute (IFPRI) discussion paper no. 1027.

Agrawal D. 2011. The tax gradient: Do local sales taxes reduce tax differentials at state borders? University of Michigan, manuscript.

Allers M, Elhorst P. 2005. Tax mimicking and yardstick competition among local governments in the Netherlands. International Tax and Public Finance 12: 493-513.

Allers M, Elhorst P. 2011. A simultaneous equations model of fiscal policy interactions. Journal of Regional Science 51: 271-291.

Allers M, Hoeben C. 2010. Effects of unit-based garbage pricing: A differences-in-differences approach. Environmental and Resource Economics 45: 405-428.

Anselin L, Le Gallo J, Jayet H. 2008. Spatial panel econometrics. In: L. Matyas and P. Sevestre, The Econometrics of Panel Data. Springer: 625-660.

Ashworth J, Geys B, Heyndels B. 2006. Determinants of tax innovation: The case of environmental taxes in Flemish municipalities. European Journal of Political Economy 22: 223-247.

Bartolini D, Santolini R. 2011. Political yardstick competition among Italian municipalities on spending decisions. Annals of Regional Science forthcoming.

Beer C, Riedl A. 2011. Modelling spatial externalities in panel data: The Spatial Durbin model revisited. Papers in Regional Science forthcoming.

Birkelof L. 2009. Intergovernmental grants and local public expenditure: Spending decisions and information spillover effects. Umeå Economic Studies no. 796. 
Birkelof L. 2010. Exploring differences in expenditure for the functionally impaired: neighborhood interaction and the federal structure. Annals of Regional Science 44: 185-204.

Bosch N, Solé-Ollé A. 2007. Yardstick competition and the political costs of raising taxes: An empirical analysis of Spanish municipalities. International and Tax Public Finance 14: 71--92.

Brown R, Rork J. 2005. Copycat gaming: A spatial analysis of state lottery structure. Regional Science and Urban Economics 35: 795-807

Brülhart M, Parchet R. 2010. Alleged tax competition: The mysterious death of inheritance taxes in Switzerland. Cahiers de Recherches Economiques du DEEP, No. 10-04.

Bruns C, Himmler O. 2011. Newspaper circulation and local government efficiency. Scandinavian Journal of Economics 113: 470--492.

Burge G, Rogers C. 2011. Local option sales taxes and consumer spending patterns: Fiscal interdependence under multi-tiered local taxation. Regional Science and Urban Economics 41: 46-58. Burge G, Piper B. 2012. Strategic fiscal interdependence: County and municipal adoptions of local option sales taxes. National Tax Journal forthcoming.

Calabrese S, Epple D. 2010. On the political economy of tax limits. Document de Treball No. 14, Institut d'Economia de Barcelona: Barcelona.

Cassette A, Di Porto E, Foremny D. 2012. Strategic fiscal interaction across borders: Evidence from French and German local governments along the Rhine-Valley. Journal of Urban Economics 72: 1730.

Charlot S, Paty S, Visalli M, Assessing the impact of local taxation on property prices: A spatial matching contribution. Applied Economics forthcoming.

Choumert J, Cormier L. 2011. The provision of urban parks: an empirical test of spatial spillovers in an urban area using geographic information systems. Annals of Regional Science 47: 437-450.

Corrado L, Fingleton B. 2011. Where is the economics in spatial econometrics? Journal of Regional Science forthcoming.

Costa-Font J, Pons-Novell J. 2007. Public health expenditure and spatial interactions in a decentralized national health system. Health Economics 16: 291--306.

Costa-Font J, Moscone F. 2008. The impact of decentralization and inter-territorial interactions on Spanish health expenditure. Empirical Economics 34: 167--184.

Dahlberg M, Edmark, K. 2008. Is there a race-to-the-bottom in the setting of welfare benefit levels? Evidence from a policy intervention. Journal of Public Economics 92: 1193-1209.

Dalle Nogare C, Galizzi M. 2011. The political economy of cultural spending: evidence from Italian 
cities. Journal of Cultural Economics 35: 203-231.

Delgado F, Mayor M. 2010. Tax mimicking among local governments: some evidence from Spanish municipalities. Portuguese Economic Journal 10: 149-164.

Delgado F, Lago-Penas S, Mayor M. 2011. On the determinants of local tax rates: New evidence from Spain. Document de Treball No. 4, Institut d'Economia de Barcelona: Barcelona.

Deskins J, Hill B. 2010. Have state tax interdependencies changed over time? Public Finance Review 38: 244-270.

Devereux M, Lockwood B, Redoano M. 2007. Horizontal and vertical indirect tax competition: Theory and some evidence from the USA. Journal of Public Economics 91: 451-479.

Di Porto E, Revelli F. 2013. Tax limited reaction functions. Journal of Applied Econometrics forthcoming.

Dubois E, Paty S. 2010. Yardstick competition: which neighbours matter? Annals of Regional Science 44: 433-452.

Edmark K, Agren H. 2008. Identifying strategic interactions in Swedish local income tax policies. Journal of Urban Economics 63: 849-857.

Elhorst P. 2010a. Applied spatial econometrics: Raising the bar. Spatial Economic Analysis 5: 9-28. Elhorst P. 2010b. Spatial panel data models. In Handbook of Applied Spatial Analysis, Fischer M, Getis A (eds). Springer: Berlin; 377-407.

Elhorst P, Freret S. 2009. Evidence of political yardstick competition in France using a two-regime spatial Durbin model with fixed effects. Journal of Regional Science 49: 931-951.

Ermini B, Santolini R. 2010. Local expenditure interaction in Italian municipalities: Do local council partnerships make a difference? Local Government Studies 36: 655-677.

Eugster B, Parchet R. 2011. Culture and taxes: Towards identifying tax competition. Manuscript, University of Lausanne, Cahiers de recherches économiques du DEEP, No. 11-05.

Feld L, Reulier E. 2009. Strategic tax competition in Switzerland: Evidence from a panel of the Swiss cantons. German Economic Review 10: 91-114.

Fiva J. 2009. Does welfare policy affect residential choices? An empirical investigation accounting for policy endogeneity. Journal of Public Economics 93: 529--540.

Fiva J, Rattso J. 2006. Welfare competition in Norway: norms and expenditures. European Journal of Political Economy 22: 202--222.

Fiva J, Rattso J. 2007. Local choice of property taxation: Evidence from Norway. Public Choice 132: 457-470. 
Flores-Lagunes A, Schnier K. 2011. Estimation of sample selection models with spatial dependence. Journal of Applied Econometrics forthcoming.

Foucault M, Madies T, Paty S. 2008. Public spending interactions and local politics. Empirical evidence from French municipalities. Public Choice 137: 57-80.

Gerard M, Jayet H, Paty S. 2010. Tax interactions among Belgian municipalities: Do interregional differences matter? Regional Science and Urban Economics 40: 336-342.

Geys B. 2006. Looking across borders: A test of spatial policy interdependence using local government efficiency ratings. Journal of Urban Economics 60: 443-462.

Geys B, Revelli F. 2011. Economic and political foundations of local tax structures: an empirical investigation of the tax mix of Flemish municipalities. Environment and Planning C: Government and Policy 29: 410-427.

Gibbons S, Overman H. 2012. Mostly pointless spatial econometrics? Journal of Regional Science 52: 172-191.

Hall J, Ross J. 2010. Tiebout competition, yardstick competition, and tax instrument choice: Evidence from Ohio school districts. Public Finance Review 38: 710-737.

Hauptmeier F, Mittermaier S, Rincke J. 2008. Fiscal competition over taxes and public inputs: Theory and evidence. CESifo Working Paper No. 2499.

Hoffer A. 2011. Spatial dependence in tobacco excise taxation: An analysis of special interest and tax competition. West Virginia University, mimeo.

Klier T, McMillen D. 2008. Clustering of auto supplier plants in the US. Journal of Business and Economic Statistics 26: 460-471.

Knight B, Schiff N. 2010. Spatial competition and cross-border shopping: Evidence from state lotteries. NBER Working Paper 15713.

Leprince M, Madies T, Paty S. 2007. Business tax interactions among local governments: An empirical analysis of the French case. Journal of Regional Science 47: 603-621.

LeSage J, Pace R. 2009. Introduction to Spatial Econometrics. Taylor and Francis: Boca Raton. LeSage J, Dominguez M. 2011. The importance of modeling spatial spillovers in public choice analysis. Public Choice forthcoming.

Lovenheim M. 2008. How far to the border? The extent and impact of cross-border casual cigarette smuggling. National Tax Journal 61: 7-33.

Luna L, Bruce D, Hawkins R. 2007. Maxing out: An analysis of local option sales tax rate increases. National Tax Journal 60: 45-63. 
Lundberg J. 2006. Spatial interaction model of spillovers from locally provided public services.

Regional Studies 40: 631-644.

Lyytikainen T. 2012. Tax competition among local governments: Evidence from a property tax reform in Finland. Journal of Public Economics forthcoming.

McMillen D. 2010. Issues in spatial data analysis. Journal of Regional Science 50: 119-141.

Moscone F, Knapp M. 2005. Exploring the spatial dimension of mental health expenditure. Journal of Mental Health Policy and Economics 8: 205--217.

Moscone F, Knapp M, Tosetti E. 2007. Mental health expenditure in England: A spatial panel approach. Journal of Health Economics 26: 842--864.

Moscone F. 2011. Geographical variations in expenditure of learning disability services in England. Applied Economics 43: 2997-3005.

Pinkse J, Slade M. 2010. The future of spatial econometrics. Journal of Regional Science 50: 103-117.

Reback R. 2011. Fiscal spillovers between local governments: Keeping up with the Joneses' school district. Barnard College, mimeo.

Revelli F. 2007. Local media networks and social spending: Evidence from the UK. Economics Letters 96: 144-149.

Revelli F. 2008. Performance competition in local media markets. Journal of Public Economics 92 : 1585-1594.

Revelli F, Tovmo P. 2007. Revealed yardstick competition: Local government efficiency patterns in Norway. Journal of Urban Economics 62: 121-134.

Rincke J. 2006a. Policy innovation in local jurisdictions: Testing for neighborhood influence in school choice policies. Public Choice 129:189-200.

Rincke J. 2006b. Competition in the public school sector: Evidence on strategic interaction among US school districts. Journal of Urban Economics 59: 352-369.

Rincke J. 2007. Policy diffusion in space and time: The case of charter schools in California school districts. Regional Science and Urban Economics 37: 526-541.

Rincke J. 2009. Yardstick competition and public sector innovation. International Tax and Public Finance 16: 337-361.

Rincke J. 2010. A commuting-based refinement of the contiguity matrix for spatial models, and an application to local police expenditures. Regional Science and Urban Economics 40: 324--330.

Rork J. 2009. Yardstick competition in toll revenues: Evidence from US states. Journal of Transport Economics and Policy 43: 123-139. 
Santolini R. 2008. A spatial cross-sectional analysis of political trends in Italian municipalities. Papers in Regional Science 87: 431--451.

Santolini R. 2009. The political trend in local government tax setting. Public Choice 139: 125-134.

Sjoquist D, Smith W, Walker M, Wallace S. 2007. An analysis of the time to adoption of local sales taxes: A duration model approach. Public Budgeting \& Finance 27: 20-40.

Stastna L. 2009. Spatial interdependence of local public expenditures: Selected evidence from the Czech Republic. Czech Economic Review 3: 7-26.

Solé-Ollé A. 2006. Expenditure spillovers and fiscal interactions: Empirical evidence from local governments in Spain. Journal of Urban Economics 59: 32-53.

Spry J. 2005. The effects of fiscal competition on local property and income tax reliance. Topics in Economic Analysis \& Policy 5: 1, Article 1.

Vermeir J, Heyndels B. 2006. Tax policy and yardstick voting in Flemish municipal elections. Applied Economics 38: 2285-2298.

Werck K, Heyndels B, Geys B. 2008. The impact of 'central places' on spatial spending patterns:

Evidence from Flemish local government cultural expenditures. Journal of Cultural Economics 32: 3558.

Wu Y, Hendrick R. 2009. Horizontal and vertical tax competition in Florida local governments. Public Finance Review 37: 289-311.

Wu Y, Merriman D. 2011. Inertia and neighboring effects in local tax policy: Illinois' experience with a local option tax on telecommunications. Public Budgeting \& Finance 31: 99-116. 